\title{
Dampak Eksekusi Rumah Tinggal terhadap Kelanjutan Pendidikan Anak Usia Sekolah Dasar
}

\author{
Karmila P. Lamadang, Pupung Puspa Ardini, Ali Kaku, Lukman A.R. Laliyo \\ ${ }^{1}$ Pendidikan Islam Anak Usia Dini Universitas Muhammadiyah Luwuk \\ ${ }^{2}$ Pendidikan Guru Pendidikan Anak Usia Dini Universitas Negeri Gorontalo \\ ${ }^{3,4}$ Pendidikan Dasar Pascasarjana Universitas Negeri Gorontalo
}

Email: karmila@gmail.co.id

\begin{abstract}
ABSTRAK
Penelitian ini bertujuan untuk mengetahui dampak pada anak-anak sekolah dasar setelah penggusuran di Tanjung Sari, Karaton, Kecamatan Luwuk, Kabupaten Banggai, Indonesia. Subjek penelitian adalah masyarakat, terutama anak-anak yang duduk di sekolah dasar bersama dengan orang tua siswa di Tanjung Sari. Prosedur Penelitian ini adalah penelitian ini menggunakan prosedur dengan tahapan meliputi sebagai berikut: tahap perencanaan, observasi dan implementasi. Dalam penelitian ini menggunakan teknik analisis kualitatif dan kuantitatif yang diperoleh melalui pernyataan responden yang terkandung dalam data kuesioner, dan kemudian untuk memeriksa keakuratan data juga dilakukan wawancara, observasi dan dokumentasi. Berdasarkan hasil penelitian yang dilakukan bahwa dampak pelaksanaan perumahan terhadap keberlanjutan pendidikan pada anak usia sekolah dasar di Tanjung Sari, Kelurahan Karwen, Kecamatan Luwuk, Kabupaten Banggai memiliki dampak yang sangat kuat terhadap kelangsungan pendidikan pada anak-anak sekolah dasar di Tanjung Sari, Karaton, Kecamatan Luwuk, Kabupaten Banggai.
\end{abstract}

Kata Kunci: Rumah Tinggal; Pendidikan; Sekolah; Siswa.

\section{ABSTRACT}

This study aims to determine the impact on elementary school children after eviction in Tanjung Sari, Karaton, Luwuk District, Banggai Regency, Indonesia. The subjects of the study were the community, especially children who sat in elementary school together with parents of students in Tanjung Sari. Procedure This research is a study using procedures with the following stages: the planning, observation and implementation stages. In this study using qualitative and quantitative analysis techniques obtained through respondents' statements contained in the questionnaire data, and then to check the accuracy of the data also conducted interviews, observations and documentation. Based on the results of research conducted that the impact of housing implementation on the sustainability of education in elementary school age children in Tanjung Sari, Karwen Village, Luwuk District, Banggai Regency has a very strong impact on the continuity of education in primary school children in Tanjung Sari, Karaton, District Luwuk, Banggai Regency.

Keywords: Residential home; Education; School; Student

(C) 2019 Karmila P. Lamadang, Pupung Puspa Ardini, Ali Kaku, Lukman A.R. Laliyo Under The License CC-BY SA 4.0 


\section{PEDAGOGIKA}

\section{Volume 10 (Nomor 1) 2019}

Hal. 44-58

\section{PENDAHULUAN}

Peran pendidikan dalam pengembangan sumber Daya manusia sangat strategis. Dalam undang-undang dasar 1945 disebutkan beberapa cita-cita bangsa Indonesia adalah untuk memajukan kesejahteraan umum mencerdasakan kehidupan bangsa dan ikut serta dalam melaksanakan ketertiban dunia. Dari cita-cita ini tentunya tidak luput dari pendidikan khususnya pendidikan dasar. Pendidikan merupakan hak setiap warga negara sebagaimana tercantum dalam Undangundang Dasar 1945 pasal 31 ayat 1 yang berbunyi bahwa setiap warga negara berhak mendapatkan pendidikan. Dalam penjelasan undang-undang tersebut bahwa tiada terkecuali semua warga negara berhak untuk mendapatkan pendidikan yang layak.

Undang-undang pendidikan nomor 23 tahun 2003 tentang Sistem Pendidikan Nasional yang berfungsi mengembangkan kemampuan berfikir serta membentuk kepribadian anak bangsa yang bermartabat, berdaya saing yang handal serta cerdas dalam bertindak dan berfikir. Selain itu tujuan dari pendidikan Indonesia sebagaimana termaktub dalam Undang-undang tersebut yakni mengasah kemampuan potensi perserta didik sehingga menjadi manusia yang berkarakter, beriman dan bertaqwa kepada Tuhan Yang Maha Esa serta memiliki akhlak mulia.
Pendidikan anak bukan hanya tanggungjawab sekolah namun merupakan tanggungjawab bersama yang meliputi keluarga, masyarakat dan pemerintah. Dalam melaksanakan pendidikan dibutuhkan lingkungan yang nyaman dan kondusif tidak hanya lingkungan sekolah tempat menimbah ilmu namun lingkungan rumah tempat tinggal dimana peserta didik menghabiskan waktunya setelah pulang dari sekolah. Ada dua faktor yang mempengaruhi kelanjutan pendidikan anak yang pertama adalah faktor internal yang meliputi kemampuan intelegensi atau kemampuan siswa, minat dan motivasi dari dalam diri siswa sendiri. Sedangkan, faktor ekternal adalah meliputi lingkungan keluarga, lingkungan sekolah serta lingkungan sosial dimana peserta didik atau siswa tinggal.Tanjung sari kelurahan Karaton merupakan salah satu daerah yang ada di kecamatan luwuk kabupaten Banggai Provinsi Sulawesi Tengah yang merupakan wilayah yang sangat strategis. Daerah tepat berada di cekungan bibir laut yang menjorok kedaratan dan berada tepat di tengah perkotaan. Sehingga menjadi lahan empuk bagi investor yang akan mengembangkan usaha perhotelan maupun perumahan mewah. Disana tinggal kurang lebih 343 kepala keluarga yang terdiri dari 1.411 jiwa tinggal dan bermukim sejak lama sudah turun temurun semenjak tahun 1960-an. 


\section{PEDAGOGIKA}

\section{Volume 10 (Nomor 1) 2019}

Hal. 44-58

Eksekusi ini dilakukan menjadi dua tahap. Tahap pertama yakni pada bulan mei 2017 yang dilakukan selama 4 hari mulai dari tanggal 3 Maret 2017 sampai dengan tanggal 6 maret 2017. Hal ini tentunya meninggalkan trauma berat bagi masyarakat yang terdampak khususnya bagi anak-anak. Banyak diantara mereka yang saat itu tak lagi mau kesekolah. Beberapa anak bahkan sering menyediri dengan tatapan kosong. Anakanak kehilangan senyum dan keceriaan. Beberapa anak mengemis dijalan dengan mengharapkan sumbangan dari setiap warga yang melewati tempat tinggal anak tersebut yang mengalami penggusuran. Hal ini seperti yang terdapat dalam sebuah penelitian yang dilakukan oleh Kahlmeter, Backman, dan Brannstrom tentang beberapa konsekuensi dari penggusuran (2018:106-119).

Belum terobati duka di bulan Mei 2017 tiba-tiba datang surat peringatan yang kedua kalinya setelah 10 bulan duka berlalu kini masyarakat yang tersisa dilahan tersebut mendapatkan surat peringatan untuk mengosongkan lahan tempat pemukiman. Hingga akhirnya terjadi penggusuran tahap ke-2 yakni tepat pada tanggal 19 Maret 2018 mereka dihadapkan dengan permasalahan pelik mulai dari kehilangan tempat tinggal, kehilangan barang berharga dan bahkan kehilangan masa bahagia bermain dengan teman-teman sebaya. Anak-anak disibukkan dengan membantu orang tuanya mengais puing-puing bangunan berharap masih ada yang bisa dimanfaatkan.

Lingkungan tempat tinggal menjadi lingkungan yang kurang nyaman dan tidak kondusif untuk belajar. Anak-anak (peserta didik) diusia sekolah dasar yang berada ditempat itu menyaksikan bagaimana alatalat berat yang dikerahkan oleh eksekutor untuk menghancurkan rumah tempat tinggal mereka. Banyak tumpahan airmata dari warga yang ada disana. Pasca eksekusi beberapa bulan kemudian sebagian anakanak korban penggusuran ini menjadi pengemis dijalan-jalan sebab orang tua mereka belum memiliki penghasilan. bantuan dari pemerintah daerah dan organisasi masyarakat dirasa tak cukup untuk memenuhi kebutuhan sehari-hari. Hal ini seperti yang terdapat dalam penelitian Berg dan Brannstrom, penggusuran dapat memberikan dampak yang buruk hingga berpengaruh juga pada kesehatan dan kesejahteraan anak (2018: 1-13).

Berdasarkan latar belakang diatas maka peneliti tertarik untuk mengambil judul penelitian "Dampak Eksekusi Rumah Tinggal Terhadap Kelanjutan Pendidikan Anak Usia Sekolah Dasar Di Tanjung Sari Kelurahan Karaton Kecamatan Luwuk Kabupaten Banggai Provinsi Sulawesi Tengah". 


\section{PEDAGOGIKA}

Volume 10 (Nomor 1) 2019

Hal. 44-58

\section{METODE PENELITIAN}

Dalam penelitian ini peneliti menggunakan penelitian mix methods, yakni suatu metode yang dilakukan dengan menggabungkan dua bentuk pendekatan , yaitu pendekatan kuantitatif dan kualitatif. Penelitian ini merupakan campuran dua pendekatan penelitian yang mengkombinasikan antara penelitian kualitatif dengan penelitian kuantitatif . Dalam penelitian ini menggunakan teknik campuran bertahap. Strategi ini adalah strategi yang dilakukan peneliti untuk menggabungkan data yang ditemukan dari satu metode dengan metode lainnya. Startegi ini dapat dilakukan dengan menginterview terlebih dahulu untuk mendapatkan data kualitatif lalu diikuti dengan data kuantitatif, dalam hal ini menggunakan survey. Subjek penelitian dalam penelitian ini adalah Siswa Sekolah Dasar yang terkena Dampak Eksekusi lahan tempat tinggal siswa dengan jumlah populasi kurang lebih 103 orang.

\section{HASIL PENELITIAN DAN PEMBAHASAN}

Berdasarkan hasil pengamatan serta wawancara yang dilakukan oleh peneliti terhadap korban eksekusi banyak hal yang peneliti temukan diataranya adalah banyak anak trauma dan tidak mau sekolah lagi disebabkan malu dan juga tak punya biaya. Misalnya : Fauzan kelas 2 Sekolah Menengah Pertama sekarang tak mau lagi sekolah disebabkan malu karena rumahnya hancur dan tidak mempunyai tempat tinggal serta tidak ada biaya untuk melanjutkan sekolah. Sinta kelas 1 Sekolah menengah Pertama sekarang sudah tak mau lagi sekolah karena tak ada biaya untuk transportasi ke sekolah. Saat ini tinggal bersama bapaknya di sebuah gubuk yang merupakan posko penjagaan polisis saat eksekusi dilakukan. Al-Magfira siswa kelas 4 Sekolah Dasar berdasarkan wawancara dengan orang tua bahwa awalnya merupakan siswa yang periang namun pasca eksekusi siswa ini sering kelihatan murung dan tidak semangat. Bahkan pasca penggusuran hampir 1 bulan tidak mau kesekolah karena baju dan perlengkapan sekolah sudah tidak ada sebab pada saat penggusuran tak sempat diselamatkan. Berdasarkan pengamatan penulis serta diskusi dengan beberapa guru memang perubahan besar terjadi pada beberapa anak yang terkena dampak eksekusi. Mereka menjadi cenderung pendiam dan tidak percaya diri.

Selain pengamatan diatas penelitipun melakukan survey kepada 103 responden dengan latar belakang yang berbeda dengan tujuan dapat menarik kesimpulan dengan baik dan melihat sudut pandang dari masingmasing responden baik yang menjadi korban penggusuran maupun masyarakat biasa yang mengetahui bahkan menyaksikan penggusuran yang dilakukan. 


\section{PEDAGOGIKA}

\section{Volume 10 (Nomor 1) 2019}

Hal. 44-58

Adapaun hasil survey dengan pilihan jawaban serta alternatif pilihan maka menggunakan angket berupa pertanyaan dan dapat dilihat pada tabel 1 sebagai berikut.

Tabel 1.Tanggapan Masyarakat Tentang Eksekusi Lahan

\begin{tabular}{ccc}
\hline Tanggapan & Jumlah Data & Presentase \\
\hline Sedih & 88 & $85 \%$ \\
Biasa Saja & 1 & $1 \%$ \\
Prihatin & 5 & $5 \%$ \\
Marah & 3 & $3 \%$ \\
Kecewa & 3 & $3 \%$ \\
Menyayangkan & 2 & $2 \%$ \\
Tidak Sesuai Prosedur & 1 & $1 \%$ \\
Jumlah Responden & $\mathbf{1 0 3}$ & $\mathbf{1 0 0 \%}$ \\
\hline
\end{tabular}

\section{Sumber: Data Primer 2019}

Berdasarkan tabel diatas pada konten tanpa sisa. Polisi atau aparat keamanan Eksekusi Lahan dengan pertanyaan ribuan personil di datangkan untuk bagiamana Tanggapan Masyarakat tentang menghadang masyarakat yang melakukan Eksekusi Lahan maka dapat dilihat bahwa perlawanan dan menahan agar rumah mereka dari 103 (seratus tiga) peserta jumlah tak dirobohkan. responden yang memberikan tanggapan sedih terhadap kasus eksekusi lahan tempat tinggal di tanjung sebesar 88 (delapan puluh delapan) responden atau $85 \%$. Sedangkan sisanya memilih dan mengatakan biasa saja, prihatin, marah, kecewa, menyayangkan dan tidak sesuai masing-masing $1 \%, 5 \%, 3 \%$, $3 \%, 2 \%$, dan $1 \%$. Hasil pengamatan dan survey yang dilakukan peneliti sangat jelas dapat terlihat bahwa baik masyarakat yang menjadi korban maupun yang tidak menjadi korban sangat terpukul melihat tempat tinggal dan pemukiman mereka dihancurkan
Pasca eksekusi banyak masyarakat yang tinggal di puing-puing reruntuhan bangunan rumah mereka dengan membangun tenda seadanya. Saat itu musim hujan dan banyak anak-anak yang kedinginan. Beberapa lembaga kemasyarakatn mendirikan dapur umum seperti Aisyiyah, Salimah, dan Partai Keadilan Sejahtera untuk menyalurkan makanan kepada masyarakat yang masih bertahan dengan mendirikan tenda-tenda darurat. 


\section{PEDAGOGIKA}

Volume 10 (Nomor 1) 2019

Hal. 44-58

Tabel 2. Masyarakat Tanjung pasca eksekusi

\begin{tabular}{ccc}
\hline Tanggapan & Jumlah data & Presentase \\
\hline Bertahan & 62 & $60 \%$ \\
Mencari tempat lain & 41 & $40 \%$ \\
Jumlah responden & $\mathbf{1 0 3}$ & $\mathbf{1 0 0 \%}$ \\
\hline
\end{tabular}

Sumber: Data Primer 2019

Dari tabel diatas konten Eksekusi Lahan dengan pertanyaan apa yang dilakukan masyarakat tanjung pasca eksekusi dapat dijelaskan bahwa dari 103 responden yang memilih bertahan 62 responden atau dapat dipresentasikan $60 \%$ sedangkan mencari tempat lain hanya sebesar 41 responden atau 40\%. Berdasarkan mengamatan peneliti memang mayoritas penduduk yang terkena eksekusi bertahan.
Berdasarkan hasil wawancara yang dilakukan peneliti kepada masyarakat yang bertahan mayoritas mengatakan bahwa mereka memilih bertahan karena memang tidak ada pilihan lain. Satu-satunya tempat tinggal mereka adalah di tanjung yang telah dirobohkan. Sedangkan, jika menyewa atau tempat lain di luar tanjung mereka tak memiliki dana. Maka pilihan satu-satunya adalah bertahan.

Tabel 3. Usaha yang dilakukan untuk menghindari penggusuran

\begin{tabular}{ccc}
\hline Tanggapan & Jumlah data & Presentase \\
\hline Mohon penangguhan & 49 & $48 \%$ \\
Melawan & 49 & $48 \%$ \\
Mencari lahan & 4 & $4 \%$ \\
Cari keadilan & 1 & $1 \%$ \\
Jumlah responden & $\mathbf{1 0 3}$ & $\mathbf{1 0 0 \%}$ \\
\hline
\end{tabular}

Sumber: Data Primer 2019

Berdasarkan pengamatan dan juga masyarakat tanjung dalam menghidari wawancara yang dilakukan peneliti baik kepada korban maupun masyarakat disekitar objek eksekusi dengan 103 responden dengan mengajukan pertanyaan apa usaha eksekusi. Maka dapat di tarik kesimpulan bahwa $48 \%$ yang menyatakan bahwa masyarakat yang terkena dampak eksekusi melakukan permohonan penangguhan dan 


\section{PEDAGOGIKA}

\section{Volume 10 (Nomor 1) 2019}

Hal. 44-58

juga $48 \%$ melakukan perlawanan. yang mereka pegang. Sedangkan, responden Perlawanan yang dimaksud disini adalah melawan aparat dan pihak yang melakukan eksekusi sebab lahan tempat tinggal mereka benar-benar milik mereka dan mempunyai izin yang sah dibuktikan dengan sertifikat yang lain mencari lahan dan mencari keadilan masing-masing $4 \%$ dan $1 \%$.

1. Sikap /persepsi orang tua terhadap kelanjutan pendidikan anak usia sekolah dasar korban eksekusi

Tabel 4. yang dilakukan orang tua dalam menyemangati anak

\begin{tabular}{ccc}
\hline Tanggapan & Jumlah data & Presentase \\
\hline Pindah tempat tinggal & 35 & $34 \%$ \\
Mengajak jalan-jalan & 58 & $56 \%$ \\
Membiarkan bermain sendiri & 4 & $4 \%$ \\
Bangun komunikasi & 1 & $1 \%$ \\
Menghibur anak & 2 & $2 \%$ \\
Membersamai & 1 & $1 \%$ \\
Memberikan semangat & 2 & $2 \%$ \\
Jumlah responden & $\mathbf{1 0 3}$ & $\mathbf{1 0 0 \%}$
\end{tabular}

\section{Sumber: Data Primer 2019}

Pada konten tentang sikap/persepsi orang tua terhadap kelanjutan pendidikan anak usia sekolah dasar yang ada dilahan eksekusi maka pada peranyaan pertama yakni apa yang dilakukan orang tua dalam menyemangati anak? Maka dapat dilihat dari 103 responden $34 \%$ yang pindah tempat tinggal, 58\% yang mengajak jalan-jalan sedangkan responden yang lain menyatakan bahwa membiarkan anak bermain sendiri
$4 \%$, bangun komunikasi $1 \%$, menghibur anak $2 \%$, membersamai $1 \%$, memberikan semangat $2 \%$. Sesuai dengan wawancara dan pengamatan peneliti pada jawaban mengajak jalan-jalan disini bukan pada mengajak jalanjalan ketempat wisata namun mengajak jalan kepada sanak keluarga yang berada di seputaran kota luwuk untuk sekedar menengakan anak-anak dari trauma anak saat melihat rumah merekadirobohkan.

Tabel 5. Hal yang dilakukan Orang tua agar anak Tetap semangat dalam melanjutkan sekolah

\begin{tabular}{ccc}
\hline Tanggapan & Jumlah data & Presentase \\
\hline Memberikan les & 1 & $1 \%$ \\
Memberikan motivasi & 102 & $99 \%$ \\
Jumlah responden & $\mathbf{1 0 3}$ & $\mathbf{1 0 0 \%}$ \\
\hline
\end{tabular}




\section{PEDAGOGIKA}

\section{Volume 10 (Nomor 1) 2019}

Hal. 44-58

Dari angket yang disebar kepada 103 responden dengan memberikan pertanyaan apa yang dilakukan bapak/ibu agar anak tetap semangat dalam melanjutkan sekolah. Maka dari tabel diatas dapat dijelaskan bahwa mayorotas responden memilih memberikan motivasi kepada anak yakni sebesar 102 responden sedang yang memberikan jawaban memberikan les hanya 1 responden atau $1 \%$ saja. Berdasarkan pengamatan peneliti bahwa masyarakat tanjung atau yang menjadi korban memberikan motivasi kepada anak dengan cara tetap mendorong anak untuk tetap sekolah.

Tabel 6. Hal yang dilakukan orang tua untuk memberikan kenyamanan kepada anak pasca eksekusi

\begin{tabular}{ccc}
\hline Tanggapan & Jumlah data & Presentase \\
\hline Memberikan pemahaman & 79 & $77 \%$ \\
Pindah rumah yang jauh & 21 & $20 \%$ \\
Cari tempat layak & 2 & $2 \%$ \\
Mengajak tetap tinggal & 1 & $1 \%$ \\
Jumlah responden & $\mathbf{1 0 3}$ & $\mathbf{1 0 0 \%}$ \\
\hline
\end{tabular}

Data Primer 2019

Pada qusionare ini peneliti memberikan pertanyaan apa yang dilakukan bapak/ibu untuk memberikan kenyamanan kepada anak pasca eksekusi. Jawaban yang diberikan oleh responden baik korban eksekusi maupun masyarakat disekitanya memilih memberikan pemahaman dengan jumlah responden 79 responden dengan presentase $77 \%$ sedangkan yang memilih pindah ditempat yang jauh adalah 21 responden atau jika dipresentasekan sebesar $20 \%$ cari tempat layak $2 \%$. Berdasarkan pengamatan dan juga wawancara secara langsung peneliti dengan masyarakat yang terkena dampak penggusuran dalam menghadapi anak khususnya anak sekolah dasar yang masih polos tak mengerti permasalahan saat bertanya kenapa rumah mereka di bongkar maka orang memberikan pemahaman kepada anak sehingga anak bisa memahami kondisi mereka yang tinggal dipuing-puing bekas rumah mereka. Selain itu juga ada yang memilih untuk pindah ditempat yang jauh sehingga anak-anak tidak trauma dan sedih melihat rumah mereka yang dihancurkan.

Tabel 7. Hal yang diakukan orang tua Pasca Eksekusi agar anak tetap semangat dalam menjalankan aktivitas

\begin{tabular}{ccc}
\hline Tanggapan & Jumlah data & Presentase \\
\hline Mendampingi & 91 & $88 \%$ \\
Memberikan bermain & 10 & $10 \%$ \\
\hline
\end{tabular}


PEDAGOGIKA

Volume 10 (Nomor 1) 2019

Hal. 44-58

\begin{tabular}{ccc}
\hline Mengajak wisata & 2 & $2 \%$ \\
Jumlah responden & $\mathbf{1 0 3}$ & $\mathbf{1 0 0 \%}$ \\
\hline
\end{tabular}

\section{DataPrimer 2019}

Pada angket yang disebar peneliti anak bermain sendiri 10 responden atau $10 \%$ kepada 103 responden dengan pertanyaan sdan yang memilih mengajak wisata 2 apa yang bapak/ibu lakukan pasca eksekusi agar anak tetap semangat dalam menjalankan aktivitas. Maka dari tabel diatas jelas terlihat responden atau 2\%. Dari pengamatan dan wawancara yang dilakukan oleh peneliti bahwa memang banyak masyarakat yang bahwa 91 responden memilih untuk hanya memilih mendampingi anak tanpa mendampingi anak pasca penggusuran atau $88 \%$. Sedangkan, yang memilih membiarkan mengajak wisata pasca eksekusi untuk menghilangkan trauma pada anak.

Tabel 8. Hal yang dilakukan Bapak/Ibu untuk memulihkan mental anak usia sekolah Dasar pasca eksekusi

\begin{tabular}{ccc}
\hline Tanggapan & Jumlah data & Presentase \\
\hline Mengajak refresing & 40 & $39 \%$ \\
Ikut trauma healing & 51 & $50 \%$ \\
Biasa saja & 12 & $12 \%$ \\
Jumlah responden & $\mathbf{1 0 3}$ & $\mathbf{1 0 0 \%}$ \\
\hline
\end{tabular}

Data primer 2019

Pada pertanyaan apa yang dilakukan bapak/ibu untuk memulihkan mental anak pasca eksekusi lahan maka mayoritas masyarakat memilih untuk mengikut sertakan anak dalam kegiatan trauma healing. Yakni sebanyak 51 responden atau $50 \%$ dari jumlah resnden sedangkan yang lain lebih memilih mengajak refresing, dan tidak melakukan apa-apa atau biasa saja. Dengan jumlah presentase masing-masing 40 dan 12 responden atau $39 \%$ dan $12 \%$.
Dari pengamatan peneliti memang pasca eksekusi berbagai organisasi melakukan kegiatan trauma healing untuk menghindari stres berat pada anak. Sehingga banyak orang tua mengikutsertakan anak pada acara tersebut. Namun refresing yang dimaksud adalah mengajak anak kesanak saudara yang diluar lokasi tempat eksekusi hanya sekedar menghibur anak agar tidak teringat pada rumah mereka yang dirobohkan.

Tabel 9. yang diakukan saat cmelihat rumah dirobohkan

\begin{tabular}{ccc}
\hline Tanggapan & Jumlah data & Presentase \\
\hline Diam-Diam & 12 & $12 \%$ \\
Menangis & 51 & $50 \%$ \\
Berontak & 25 & $24 \%$ \\
Berdoa & 15 & $14 \%$ \\
Jumlah responden & $\mathbf{1 0 3}$ & $\mathbf{1 0 0 \%}$ \\
\hline
\end{tabular}




\section{PEDAGOGIKA}

\section{Volume 10 (Nomor 1) 2019}

Hal. 44-58

Apa yang bapak/ibu lakukan saat melihat rumah dirobohkan. saat pertanyaan ini dilontarkan kepada responden baik yang menjadi korban maupun tidak. Maka mayoritas responden mengatakan menangis yakni 51 responden atau 50\%. Sedangkan responden lain memilih berdoa, berontak, dan mencari keadilan. Dengam masingmasing presentasi $25 \%, 15 \%$, dan $12 \%$.
Berdasarkan pengamatan peneliti memang benar bahwa pada saat eksekusi banyak masyarakat tak bisa melakukan apaapa kecuali menangis sebab banyaknya personil aparat yang di datangkan oleh pihak yang melakukan eksekusi. Bahkan barisan ibu-ibu yang melakukan penghadangan dengan melakukan zikir dan do'a disiram dengan gas air mata.

Tabel 10. Upaya yang dilakukan dalam kasus eksekusi lahan

\begin{tabular}{ccc}
\hline Tanggapan & Jumlah Data & Presentase \\
\hline Ganti Untung & 4 & $4 \%$ \\
Minta Ganti Rugi & 67 & $65 \%$ \\
Mengikhlaskan & 4 & $4 \%$ \\
Melawan & 28 & $27 \%$ \\
Jumlah Responden & $\mathbf{1 0 3}$ & $\mathbf{1 0 0 \%}$ \\
\hline
\end{tabular}

Data Primer 2019

Upaya apa yang bapak/ibu lakukan dalam kasus ini. Saat pertanyaan ini di tanyakan kepada 103 responden maka mayoritas masyarakat mengatakan minta ganti rugi dengan presentase $65 \%$. Sedangkan responden lain mengatakan melakukan perlawanan, minta ganti untung dan mengikhlaskan dengan presentase masing-masing $28 \%$ dan $4 \%$.

Dalam wawancara serta pengamatan peneliti memang bahwa masyarakat sangat menginginkan ganti rugi terhadap harta benda mereka khususnya rumah yang dirobohkan sebab itu merupakan tempat tinggal mereka, tempat berkumpul bersama keluarga dan tempat membesarkan anakanak mereka. Terlihat sampai saat ini masih banyak masyarakat yang tinggal dan bertahan di karena belum mampu membangun kembali rumah mereka pasca dibatalkannya putusan peradilan oleh Pengadian Negeri.

2. Dampak eksekusi lahan terhadap anak usia sekolah dasar yang tinggal di lahan eksekusi

Tabel 11. sikap anak yang terkena Dampak eksekusi pasca penggusuran

\begin{tabular}{ccc}
\hline Tanggapan & Jumlah Data & Presentase \\
\hline Menghayal & 30 & $29 \%$ \\
Tidak Fokus & 67 & $65 \%$ \\
\hline
\end{tabular}




\section{PEDAGOGIKA}

Volume 10 (Nomor 1) 2019

Hal. 44-58

\begin{tabular}{ccc}
\hline Biasa Saja & 6 & $6 \%$ \\
Jumlah Responden & $\mathbf{1 0 3}$ & $\mathbf{1 0 0 \%}$ \\
\hline
\end{tabular}

Data Primer 2019

Dari 103 responden yang disodorkan dengan pertanyaan Bagaimana sikap anak yang terkena dampak pengusuran masyarakat yang mengetahui persis penggusuran mengatakan bahwa anak-anak yang terkena dampak eksekusi tidak fokus dengan presentase $65 \%$. Hal ini terlihat dengan tidak semangatnya anak-anak dalam menerima pelajaran hal inipun dituturkan oleh beberapa guru yang menangani anak korban eksekusi. Sedangkan yang memilih sering menghayal dan biasa saja masing- masing 29\% dan 6\%. Hal ini dikuatkan dengan wawancara langsung dengan penuturan beberapa guru yang menjadi wali kelas anak yang menjadi korban penggusuran bahwa memang terjadi perbedaan antara sebelum dan sesudah eksekusi tempat tinggal mereka. Pasca eksekusi kelihatannya mereka tidak fokus dalam mengikuti proses belajar mengajar disekolah, paling banyak diam dan tidak semangat.

Tabel 12. Sikap anak dalam menerima pelajaran di Sekolah

\begin{tabular}{ccc}
\hline Tanggapan & Jumlah data & Presentase \\
\hline Biasa saja & 15 & $15 \%$ \\
Tidak semangat & 83 & $81 \%$ \\
Malas & 5 & $5 \%$ \\
Jumlah responden & $\mathbf{1 0 3}$ & $\mathbf{1 0 0 \%}$ \\
\hline
\end{tabular}

\section{Data Primer 2019}

Bagaimana sikap anak dalam mengatakan memang kelihatannya sangat menerima pelajaran di sekolah. Dari 103 berbeda sikap anak saat sebelum responden yang menyatakan bahwa tidak penggusuran dan pasca penggusuran. Jika semangat sebanyak 88 responden atau jika sebelum penggusuran mereka rajin ke dipresentasekan sebesar $85 \%$. Sedangkan sekolah semangat belajar sedangkan pasca yang lain menyatakan biasa saja dan malas. eksekusi mereka kelitannya tidak semangat.

Dengan presentase $15 \%$ dan 5\%. Dan

Tabel 13. Hal yang dilakukan anak yang terkena dampak eksekusi

\begin{tabular}{ccc}
\hline Tanggapan & Jumlah data & Presentase \\
\hline Sering melamun & 72 & $71 \%$ \\
Bermain seperti biasa & 30 & $29 \%$ \\
Hanya diam & 1 & $1 \%$ \\
Jumlah responden & $\mathbf{1 0 2}$ & $\mathbf{1 0 0 \%}$ \\
\hline
\end{tabular}




\section{PEDAGOGIKA}

Volume 10 (Nomor 1) 2019

Hal. 44-58

Dari tabel diatas maka dapat dijelaskan bahwa saat peneliti memberikan pertanyaan apa yang dilakukan anak yang terkena dampak eksekusi. Pertanyaan ini diberikan kepada 103 responden dan hasilnya 72 (tujuh puluh dua) atau $70 \%$ responden menyatakan anak yang terkena dampak eksekusi sering melamun sedang responden yang lain menyatakan biasa saja sebanya 31 responden atau jika di presentasekan sebesar 30\%. Hal ini sesuai dengan pengamatan guru-guru yang disekolah sebagaimana hasil wawancara peneliti dan beberapa guru mereka mengatakan bahwa memang anakanak korban penggusuran seringkali terlihat melamun dan tidak seceria sebelum eksekusi.

Berdasarkan hasil analisis yang dilakukan bahwa dampak eksekusi rumah tinggal terhadap keberlanjutan pendidikan anak usia sekolah dasar di Tanjung Sari Kelurahan Karaton Kecamatan Luwuk Kabupaten Banggai memiliki dampak yang sangat kuat terhadap keberlanjutan pendidikan anak usia sekolah dasar di Tanjung Sari. Hal ini sesuai dengan hasil wawancara yang telah ditulis oleh peneliti sebelumnya bahwa sebagian besar mengatakan bahwa eksekusi lahan ini sangat mempengaruhi keberlanjutan pendidikan anak.sebab eksekusi lahan tempat tinggal sangat mempengaruhi psikologi anak. Banyak anak yang depresi dan stres. Karena melihat secara langsung tempat tinggal mereka yang selama ini menjadi tempat yang nyaman, temat berkumpul dengan keluarga, teman dirobohkan dengan alat-alat berat. Hal ini juga didukung oleh beberapa penelitian sebelumnya yang dilakukan oleh Desmond, An, Winkler dan Ferriss, bahwa penggusuran sangat berdampak dan beresiko untuk anakanak (2013: 303-327).

Dalam berbagai literatur ilmu sosial, pembangunan atau yang disebut dengan istilah apapun, semestinya diarahkan pada penciptaan kesejahteraan warganya. Itu berarti, tujuan utama pembangunan adalah kesejahteraan manusia (Human Welfare). Pembangunan yang mensejahterakan rakyat akan memperoleh keberhasilan, jika dilakukantanpa penggusuran paksa. Fakta membuktikan bahwa penggusuran paksa merupakanfaktor utama penyebab kemiskinan di kota Asia (Kahlmeter, et.all: 2018).

Dampak secara sederhana bisa diartikan sebagai pengaruh atau akibat. Dalam setiap keputusan yang diambil oleh seorang atasan biasanya mempunyai dampak tersendiri, baik itu dampak positif maupun dampak negatif. Dampak juga bisa merupakan proses lanjutan dari sebuah pelaksanaan pengawasan internal. Seorang pemimpin yang handal sudah selayaknya bisa memprediksi jenis dampak yang akan terjadi atas sebuah keputusan yang akan diambil. Dari penjabaran diatas maka kita 


\section{PEDAGOGIKA}

\section{Volume 10 (Nomor 1) 2019}

Hal. 44-58

dapat membagi dampak ke dalam dua pengertian yaitu;

a. Pengertian Dampak Positif

Dampak adalah keinginan untuk membujuk, meyakinkan, mempengaruhi atau memberi kesan kepada orang lain, dengan tujuan agar mereka mengikuti atau mendukung keinginannya. Sedangkan positif adalah pasti atau tegas dan nyata dari suatu pikiran terutama memperhatikan hal-hal yang baik. positif adalah suasana jiwa yang mengutamakan kegiatan kreatif dari pada kegiatan yang menjemukan, kegembiraan dari pada kesedihan, optimisme dari pada pesimisme. Positif adalah keadaan jiwa seseorang yang dipertahankan melalui usaha-usaha yang sadar bila sesuatu terjadi pada dirinya supaya tidak membelokkan fokus mental seseorang pada yang negatif.

Bagi orang yang berpikiran positif mengetahui bahwa dirinya sudah berpikir buruk maka ia akan segera memulihkan dirinya. Jadi dapat disimpulkan pengertian dampak positif adalah keinginan untuk membujuk, meyakinkan, mempengaruhi atau memberi kesan kepada orang lain, dengan tujuan agar mereka mengikuti atau mendukung keinginannya yang baik.

\section{b. Pengertian Dampak Negatif}

Dalam kamus besar Bahasa Indonesia dampak negatif adalah pengaruh kuat yang mendatangkan akibat negatif. Dampak adalah keinginan untuk membujuk, meyakinkan, mempengaruhi atau memberi kesan kepada orang lain, dengan tujuan agar mereka mengikuti atau mendukung keinginannya. berdasarkan beberapa penelitian ilmiah disimpulkan bahwa negatif adalah pengaruh buruk yang lebih besar dibandingkan dengan dampak positifnya.

Jadi dapat disimpulkan pengertian dampak negatif adalah keinginan untuk membujuk, meyakinkan, mempengaruhi atau memberi kesan kepada orang lain, dengan tujuan agar mereka mengikuti atau mendukung keinginannya yang buruk dan menimbulkan akibat tertentu.

Dalam kajian teori ini akan dibahas beberapa kajian mengenai permukiman sebagai hak dasar, perkembangan permukiman liar, permukiman di bantaran sungai, penggusuran, dan upaya penanganan permukiman liar.

Permukiman sebagai Hak Dasar Hak dasar adalah hak setiap orang untuk dapat menikmati kehidupan yang bermartabat dan hak yang diakui dalam peraturan perundangundangan. Salah satu hak dasar ini adalah hak atas perumahan. Dalam UUD 1945 pasal $38 \mathrm{H}$ ayat 1 disebutkan bahwa: Setiap orang berhak hidup sejahtera lahir dan batin, bertempat tinggal, dan mendapatkan lingkungan hidup yang baik dan sehat serta berhak memperoleh pelayanan kesehatan (Setiawan, 2010). 


\section{PEDAGOGIKA}

\section{Volume 10 (Nomor 1) 2019}

Hal. 44-58

Dalam Undang-Undang No. 4 Tahun 1992 tentang Perumahan dan Permukiman dijelaskan mengenai Hak dan Kewajiban Warga Negara dalam hal Perumahan.

Hak dan kewajiban tersebut adalah:

1. Setiap warga negara mempunyai hak untuk menempati dan/atau menikmati dan/atau memiliki rumah yang layak dalam lingkungan yang sehat, aman, serasi, dan teratur.

2. Setiap warga negara mempunyai kewajiban dan tanggung jawab untuk berperanserta dalam pembangunan perumahan dan permukiman.

Definisi rumah dalam UU No. 4 Tahun 1992 adalah bangunan yang berfungsi sebagai tempat tinggal atau hunian dan sarana pembinaan keluarga. Definisi ini menunjukkan bahwa rumah tidak hanya berfungsi untuk tempat tinggal, melainkan juga untuk membangun hubungan sosial dan lingkungan. Tanpa campur-tangan pihak lain dari luar lingkungan, mereka pun akan mengusahakan penyelenggaraan rumah dan permukimannya sendiri secara mandiri dan berdaulat (Setiawan, 2010).

Pelayanan dasar dan infrastruktur: Sebuah tempat tinggal harus memiliki fasilitas yang memberikan kesehatan, keamanan, kenyamanan dan dukungan seperti air minum, bahan bakar untuk memasak, memanaskan, penerangan, sebuah rumah tangga untuk memenuhi kebutuhannya. Dapat ditinggali Sebuah tempat tinggal harus mampu melindungi penghuninya dari udara dingin, panas, hujan atau ancaman terhadap kesehatan lainnya (Desmond, 2013).

Pendidikan adalah usaha sadar dan terencana untuk mewujudkan suasana belajar yang kreatif dan mandiri, agar peserta didik secara aktif dan mandiri. Selain itu pendidikan juga bertujuan untuk menciptakan genarasi yang handal, memiliki spritual keagamaan, pengendalian diri, kepribadian, kecerdasan dan akhlak mulia serta keterampilan yang diperlukan dirinya masyarakat bangsa dan negara (Ali dan Asrori, 2004).

Sekolah sebagai suatu lembaga pendidikan formal, secara sistematis merencanakan bermacam-macam lingkungan, yakni lingkungan pendidikan yang menyediakan berbagai macam kesempatan bagi peserta didik untuk melakukan berbagai kegiatan belajar. Dengan berbagai kesempatan belajar itulah, pertumbuhan dan perkembangan peserta didik dapat diarahkan dan didorong kepencapaian tujuan yang dicitacitakan. Lingkungan tersebut disusun dan ditata dalam suatu kurikulum pendidikan, yang pada gilirannya akan dilaksanakan dalam bentuk proses belajar mengajar (Effendi, 2018). Kepedulian menjadikan individu terkait dengan orang lain dan apapun yang 


\section{PEDAGOGIKA}

\section{Volume 10 (Nomor 1) 2019}

Hal. 44-58

terjadi terhadap orang tersebut. Orang yang mengutamakan kebutuhan dan perasaan orang lain daripada kepentingannya sendiri adalah orang yang peduli. Orang yang peduli tidak akan menyakiti perasaan orang lain. Mereka selalu berusaha untuk menghargai, berbuat baik, dan membuat yang lain senang. Banyak nilai yang merupakan bagian dari kepedulian, seperti kebaikan, dermawan, perhatian, membantu, dan rasa kasihan. Kepedulian juga bukan merupakan hal yang dilakukan karena mengharapkan sesuatu sebagai imbalan.

\section{KESIMPULAN}

Berdasarkan hasil penelitian maka peneliti dapat menyimpulkan beberapa hal Bahwa eksekusi lahan tempat tinggal di Tanjung Sari Kelurahan Karaton Kecamatan Luwuk sangat mempengaruhi keberlanjutan sekolah Anak khususnya anak usia sekolah Dasar. Dampak yang ditimbulkan oleh eksekusi lahan ini tidak hanya terjadi pada bidang pendidikan anak namun merambah kesegala arah baik ekonomi, maupun sosial. Eksekusi ini mengganggu stabilitas keamanan kabupaten banggai dan lebih khusus kecamatan luwuk.

\section{REFERENSI}

Mohammad Ali, M. A. (2004). Psikologi Remaja: Perkembangan Peserta Didik. Jakarta : Bumi Aksara.
Babbie, Earl (2009) The Practice of Sosial Research. California: Wadsworth, Publishing Company

Berg, Lisa dan Brannstrom, Lars, Evicted Children and Subsequent Placement in out-home- care : A cohort study, PLOS One 13 (4),2018. http : // doi.org/10.1371/journal.pone.01952 95.

Desmond, Matthew, An Weihua, Winkler Richelle, and Ferriss Thomas, Evicting Children Social Force92(1)2013DOI $10.1093 /$ sf/sot047.

Effendi, Mursilah, dan Titian, Mujiono, Korelasi Tingkat Perhatian Orang Tua dan Kemandirian Belajar dengan Prestasi Belajar Siswa Ilmu: Jurnal Ilmiah Multi Sciences, Vol. 10 No. 1, Halaman: 17-23, Januari 2018 DOI $\underline{10.30599 / j t i . v 10 i 1.131}$

Kahlmeter Anna, Backman Olof, and Brannstrom Lars, Housing Evictions,and economic hardship, a prospective study, Europian Sosiological Review Volume 34 Issue I,2018. DOI 10.1093/esr/jcx.087

Setiawan, Rulli Pratiwi, Penggusuran Permukiman Liar di Stren Kali Jagir: Sebuah Tinjauan dari Sisi Hukum dan Humanisme 1) Unpublished 2010 Language Malay Identifier DOI: 10.13140/RG.2.1.1044.5283

Undang-undang nomor 23 tahun 2003 tentang Sistem Pendidikan Nasional. 